\title{
Spermatogenesis does not require the local production of follistatin
}

\author{
S-Y Lin, J R Morrison, M M Matzuk ${ }^{1}$ and D M de Kretser \\ Monash Institute of Medical Research, Monash Medical Centre, 246 Clayton Road, Clayton, Victoria 3168, Australia \\ and ${ }^{1}$ Departments of Pathology, Molecular and Cellular Biology and Molecular and Human Genetics, Baylor \\ College of Medicine, Houston, Texas 77030, USA
}

Correspondence should be addressed to D M de Kretser; Email: david.de.kretser@med.monash.edu.au

S-Y Lin is now at Department of Obstetrics and Gynaecology, Mackay Memorial Hospital, Taipei, Taiwan

\begin{abstract}
It has been proposed that follistatin can modulate the actions of activins and/or other members of the transforming growth factor$\beta$ superfamily of proteins on testicular function, since mice overexpressing follistatin showed spermatogenic disruption.

However, since mice with targeted disruption of the follistatin gene die soon after birth, it is not feasible to determine the effect of the absence of follistatin on testicular function using this model. To further understand the role of follistatin on the development and maintenance of spermatogenesis, fetal testes, collected by Caesarean section at day 18 of gestation from follistatin null mice, were transplanted to the external ear of castrated recombination activating gene 1 immunocompromised male mice. The testicular grafts were then analysed 7-8 weeks after transplantation and showed that full spermatogenesis developed in both the testes of wild-type and follistatin null mice. This study indicates that, if follistatin is required to modulate spermatogenic development, it is not supplied by local testicular production but by circulating follistatin from the host mouse.

Reproduction (2006) 132 601-605
\end{abstract}

\section{Introduction}

The inhibins and activins were isolated from the gonads on the basis of their capacity to specifically modulate follicle-stimulating hormone (FSH) secretion. The activins stimulate, whereas the inhibins suppress FSH (Robertson et al. 1985, Ling et al. 1986, Vale et al. 1986). Follistatin, a glycosylated single-chain protein with no structural similarity to inhibin, can suppress FSH secretion by pituitary cells (Robertson et al. 1987, Ueno et al. 1987), an action subsequently shown to be due to its capacity to bind and neutralize the actions of the activins (Nakamura et al. 1990). Follistatin is produced in two forms through an alternative splicing event to produce follistatin 288 , which binds to heparin sulphate proteoglycans and is considered locally active (Esch et al. 1987). A larger form, follistatin 315, does not bind to heparin sulphate proteoglycans and is considered to be a circulating form. Recent data also indicate that follistatin can bind other members of the transforming growth factor- $\beta$ superfamily of proteins, namely bone morphogenetic proteins (BMP) 2, 4, and 7, albeit with less than $10 \%$ of its affinity for activin (lemura et al. 1998,
Glister et al. 2004), thereby expanding the potential physiological functions of this protein.

The activins and inhibins have been shown to have local actions within the testis. Activin A enhanced spermatogonial proliferation in vitro (Mather et al. 1990, Hakovirta et al. 1993) and promoted the reaggregation of Sertoli and germ cells in the absence of basement membranes and peritubular cells (van Dissel-Emiliani et al. 1989, Mather et al. 1993). In contrast, the inhibins suppressed spermatogonial proliferation when injected locally into the adult hamster testis (van Dissel-Emiliani et al. 1989). Activin A has also been shown to synergise with $\mathrm{FSH}$ in the stimulation of Sertoli cell proliferation (Buzzard et al. 2003) and exerts temporal-specific actions on the transformation of gonocytes to spermatogonia (Meehan et al. 2000). Follistatin antagonized the ability of activin A to aggregate Sertoli cell monolayers but did not inhibit the activin-induced stimulation of spermatogonia grown in co-culture with Sertoli cells (Mather et al. 1993).

Study of the action of follistatin on testicular function by targeted disruption of the follistatin gene in mice was not possible, since these mice had multiple defects in 
other organs that resulted in death immediately after birth (Matzuk et al. 1995). However, transgenic mice overexpressing follistatin showed variable levels of disruption of spermatogenesis and Leydig cell hyperplasia, either acting through the neutralisation actions of the activins or the BMPs that can bind to follistatin (Guo et al. 1998). Evidence of a direct action of activin A on the testis emerged in transgenic mice overexpressing the activin $\beta_{A}$ subunit gene, which showed disruption of spermatogenesis (Tanimoto et al. 1999). Evidence of actions of BMP-4, 8-B and 8-A have emerged from studies of targeted disruption of these genes in mice indicating their importance in primordial germ cell generation, and the initiation and maintenance of spermatogenesis (Zhao et al. 1996, 1998, Lawson et al. 1999, Ying et al. 2000).

Given the actions of activin A and certain BMPs on the development of the testis, we set out to evaluate the development of testes from follistatin null mice by transplanting testes from these and wild-type mice to the external ear of castrated immunocompromised male mice, in order to determine if circulating follistatin 315, provided by the recipient could support testis development in the absence of locally produced follistatin by the transplanted donor mouse testicular tissue.

\section{Materials and Methods}

\section{Experimental animals}

C57/129 hybrid mice, heterozygous for the deleted follistatin allele were used to produce follistatin null offspring (Matzuk et al. 1995). The testes were collected from fetuses delivered by Caesarean section at day 18 of gestation. Graft recipients were 8-9-week-old recombination activating gene (RAG) male mice that were immunodeficient and do not produce mature $\mathrm{T}$ or $\mathrm{B}$ lymphocytes. All mice were obtained from Monash Animal Services, Monash University, Australia and housed under a $12 \mathrm{~h}$ light: $12 \mathrm{~h}$ darkness cycle at $22^{\circ} \mathrm{C}$. This study was approved by Monash Medical Centre Animal Ethics Committee (MMCA 2000/43) and conforms to the conditions laid down by the NHMRC/ CSIRO/AAC Australian Code of Practice for the Care and Use of Animals for Scientific Purposes (1997).

\section{Collection of fetal testes for transplantation}

Following decapitation of the fetus, the abdomen was opened and the testes, epididymis and part of the vas were removed and transferred into Dulbecco's PBS (GibcoBRL, Life Technologies) at room temperature until transplantation. The tail of each donor fetus was removed for subsequent genotyping.

\section{Transplantation and castration procedures}

All procedures were performed in an specific pathogenfree room and sterile techniques were used for all procedures. Mice were anaesthetized by an i.p. injection solution of $0.5 \mathrm{ml}$ Rompun (Xylazil 20, $20 \mathrm{mg} / \mathrm{ml}$ ), $0.5 \mathrm{ml}$ ketamine $(100 \mathrm{mg} / \mathrm{ml})$ and $9 \mathrm{ml}$ PBS. A single dose of $0.3-0.45 \mathrm{ml}$ was usually sufficient for most mice. The 8-9 week-old male mice were castrated through small scrotal incisions. Subsequently, following removal of the epididymis and vas, the fetal testes were transplanted into the recipient's external ears using a technique similar to that previously reported for the rat (Johnson et al. 1996). A $1.5 \mathrm{~mm}$ opening was made on the dorsal surface of the pinna at a point about two-thirds of the distance from the tip of the ear. Through it, a channel was formed under the skin toward the ear tip by blunt, gentle dissection. The tip of the channel was pierced by a fine needle and the fetal testicular graft was inserted through this opening. The wound in the ear was self-sealing and did not require sutures.

Each recipient received one pair of testes from a single donor fetus and when the genotyping of the donor was complete, the RAG mice receiving grafts from mice heterozygous for the deletion of the follistatin gene were killed $24 \mathrm{~h}$ later. Only mice receiving testes from wildtype mice and mice homozygous for the deletion of the follistatin gene were allowed to survive until 7-8 weeks after transplantation.

\section{Genotyping}

A tail biopsy of $1.5 \mathrm{~mm}$ from each fetus was digested in $100 \mu \mathrm{l}$ lysis buffer $(10 \mathrm{mM}$ Tris-HCl $(\mathrm{pH}$ 8.3), $50 \mathrm{mM}$ $\mathrm{NaCl}$ and $0.2 \%$ Tween 20) plus $1 \mu \mathrm{l}$ proteinase $\mathrm{K}$ $(19 \mathrm{mg} / \mathrm{ml})$ at $55^{\circ} \mathrm{C}$ for $65 \mathrm{~min}$, then at $98{ }^{\circ} \mathrm{C}$ for $12 \mathrm{~min}$, and kept on ice to perform PCR later. Two pairs of PCR primers, which were the pair of hHPRT.3F (5'-TGCTGACCTGCTGGAATTACA-3') and hHPRT.3R (5'-CTGCATTGTTTTGCCAGTGT-3') and the pair of Foldel.F (5'-CGCTGCCAGGTCCTGTATAA- $3^{\prime}$ ) and Foldel.R (5'-CTTTACAAGGGATGCAGTTGG-3'), were used for differentiating the homozygous and heterozygous state for the deleted follistatin allele, and wild type. The PCR conditions were set up at the initial denaturation of $94{ }^{\circ} \mathrm{C}$ for $5 \mathrm{~min}$, followed by 35 cycles of $94{ }^{\circ} \mathrm{C}$ for $30 \mathrm{~s}$, $58{ }^{\circ} \mathrm{C}$ for $30 \mathrm{~s}$ and $72{ }^{\circ} \mathrm{C}$ for $30 \mathrm{~s}$, and with final extension at $72{ }^{\circ} \mathrm{C}$ for $5 \mathrm{~min}$. hHPRT.3F and hHPRT.3R were used for targeting the replacement cassette of the deleted mouse follistatin gene. The PCR products from the primer pair of hHPRT.3F and hHPRT.3R were $208 \mathrm{bp}$ in size. Therefore, when there was a band of $208 \mathrm{bp}$, the genotype of the pup should be a heterozygote or a homozygote of the follistatin knockout. Foldel.F and Foldel.R were used for targeting the mouse follistatin gene. The PCR products from the primer pair of Foldel.F and Foldel.R were $157 \mathrm{bp}$ in size. Therefore, when there 
was a band of $157 \mathrm{bp}$, the genotype of the pup should be a wild-type or a heterozygous follistatin mutant. Thus, the combination of these two pairs of primers enabled the definition of the genetic status of the pups. The possible results from PCR genotyping were shown in a picture of the gel in Fig. 1.

\section{Histological analysis of testicular grafts}

The testes were removed from the external ear and placed in Bouin's fixative for $3-5 \mathrm{~h}$ and after transfer to $70 \%$ ethanol, the tissue was dehydrated and embedded in paraffin wax. The testes were serially sectioned at a thickness of $5 \mu \mathrm{m}$, stained by the periodic acid Schiff's reagent and counter stained with $1 \%$ Harris' haematoxylin for $1 \mathrm{~min}$. Following dehydration, the sections were mounted in DPX (BDH, Poole, Dorset, UK) and cover-slipped (Fig. 2).

Multiple sections from each transplanted testis were evaluated qualitatively to determine whether testicular development had progressed from the stage at day 18 of gestation when they were transplanted. Subsequently, the sections from each testis were assessed semiquantitatively by determining the percentage of seminiferous tubules that showed full development of spermatogenesis. The statistical significance of these results was evaluated by the independent samples $t$-test.

\section{Results}

\section{Growth of the testicular grafts}

All grafts survived. The grafted testes increased in size in their position on the dorsal surface of the external ear with the increase in testis volume ranging from 50- to 100-fold.

In total, 22 male fetuses were collected for this study, of which 7 were homozygous for the follistatin gene deletion, 11 were heterozygous and 4 were wild type. The 11 RAG mice receiving the grafts from the heterozygous donors were killed as soon as the results of genotyping were known. Unfortunately, four of the

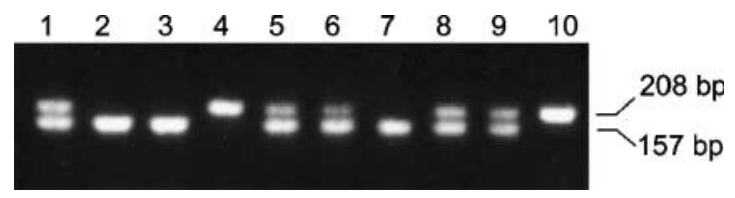

Figure 1 PCR for genotyping the pups. This picture provides an example of the genotyping results. The PCR reactions were run with two pairs of primers: hHPRT.3F and hHPRT.3R; Foldel.F and Foldel.R. The PCR products from the primer pair of hHPRT.3F and hHPRT.3R were $208 \mathrm{bp}$ in length, targeting the replacement cassette of the sequences in the knocked-out follistatin gene. The PCR products from the primer pair of Foldel.F and Foldel. $R$ were $157 \mathrm{bp}$ in length, targeting the sequences of the mouse follistatin gene. Thus, lanes 2, 3 and 7 represent wild-type pups, lanes 1, 5, 6, 8 and 9 represent the follistatin-deleted heterozygotes. Lanes 4 and 10 represent the follistatin knockout pups.

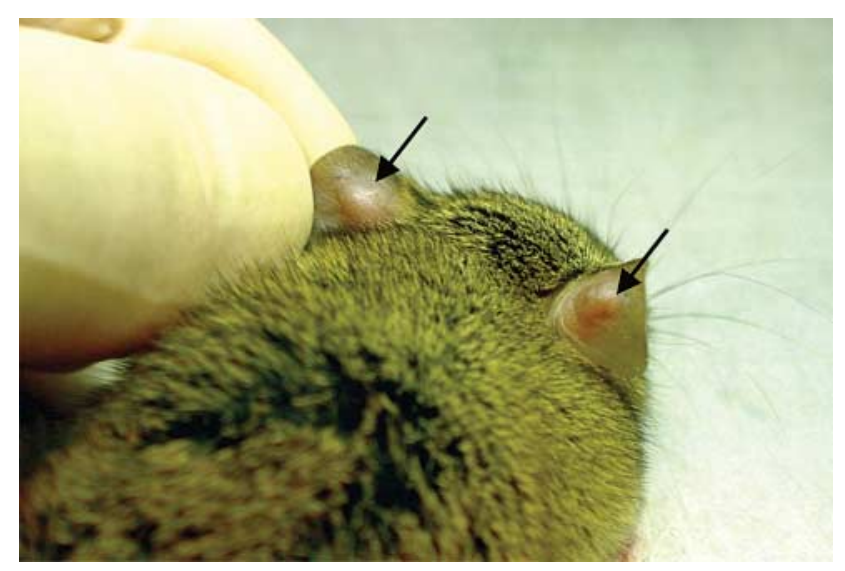

Figure 2 Fetal testes that have enlarged in the external ears of the adult castrated RAG male mouse are shown (indicated by arrows).

seven RAG mice receiving grafts from the homozygous mice died for unknown reasons some days after the transplantation surgery. The final analysis was thus performed on six follistatin null and eight wild-type testis grafts which were evaluated when the recipients were killed between 7 and 8 weeks post-transplantation.

\section{Histological assessment}

The morphological features of the follistatin null and wild-type fetal testes at day 18 of gestation showed no significant differences (Fig. 3a and d). The testes consisted of seminiferous cords composed of immature Sertoli cells with peripherally placed nuclei and gonocytes that lie predominantly within the centre of the cords. Groups of fetal Leydig cells, characterised by their large size and ovoid nuclei, were present within the inter-tubular tissue.

At 7-8 weeks post-transplantation, there were no significant differences between the grafted wild-type and follistatin null testes (Fig. $3 \mathrm{~b}$ and e). The grafted testes had increased in volume and the seminiferous tubules had expanded with the seminiferous epithelium showing all types of germ cells from spermatogonia through to mature, stage 19 spermatids. In many seminiferous tubules from testes and from both genetic backgrounds, there was evidence of luminal distension and disorganization of spermatogenesis with premature sloughing of groups of post-meiotic germ cells (Fig. 3c and f). In some tubules, only Sertoli cells could be found in the epithelium. The loss of germ cells made assessment of the stages of spermatogenesis difficult in both wild-type and follistatin null testes. However, the presence of step 16 spermatids together with the appropriate basally placed germ cells at stage VII of the cycle (Fig. 3b, follistatin null) and the appearance of a typical stage I (Fig. 3e, wild type) suggests that the typical cell associations of spermatogenesis are maintained at this ectopic site. 

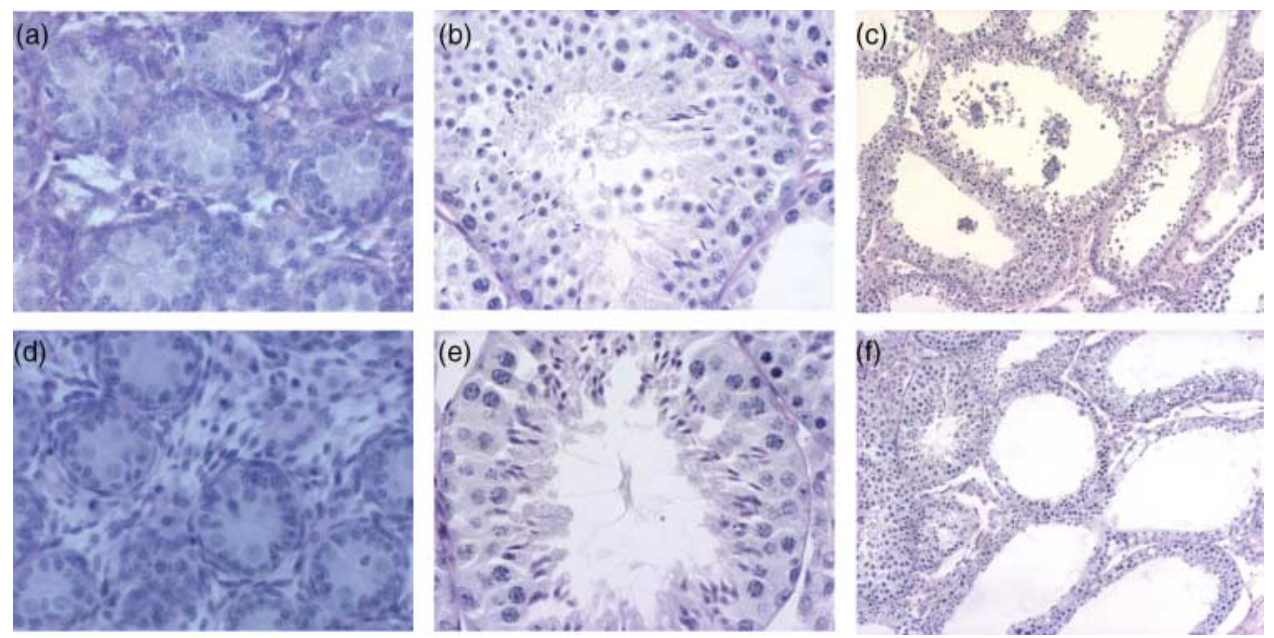

Figure 3 Spermatogenesis in testes transplanted into the outer ears of RAG mice. (a) Follistatin knockout fetal testis; (d) wild-type fetal testis; (b) and (c) follistatin knockout grafted testes after 7-8 weeks of transplantation; (e) and (f) wild-type knockout grafted testes after 7-8 weeks of transplantation. The pictures of (a), (b), (d) and (e) are $40 \times$ magnification and those of (c) and (f) are $10 \times$ magnification. Note the similar histological appearances before transplantation of the follistatin knockout and wild-type fetal testes (a) and (d). After transplantation, the testes show seminiferous tubules with full spermatogenesis (b) and (e). Some seminiferous tubules displayed an enlarged lumen with disorganization of epithelium and premature sloughing of post-meiotic germ cells (c) and (f).

The percentages of seminiferous tubules containing germ cells were not significantly different between the two groups (follistatin null $85.9 \pm 3.7 \%$ vs wild type $83.7 \pm 5.1 \%)$. The number of seminiferous tubules with complete spermatogenesis also showed no differences between the two genotypic groups (follistatin null 18.6士 $1.3 \%$ vs wild type $19.8 \pm 1.7 \%$ ).

\section{Discussion}

This study demonstrates that fetal testes from follistatin null mice can progress to complete spermatogenesis when transplanted into the external ear of castrated immunodeficient recipient mice. There were no obvious differences between the testes of the follistatin null mice and those of wild-type mice used as controls. Since the germ cells, Sertoli cells and Leydig cells of the follistatin null mice are unable to produce either follistatin 288 or 315 , the results of this experiment indicate that the local production of these proteins is not critical to the completion of spermatogenesis. However, the host RAG mice are able to produce both forms of follistatin and, since follistatin 288 is predominantly tissue-bound to cell surfaces or basement membranes owing to its strong affinity for heparan sulphate proteoglycans, if follistatin is shown to be required to modulate the actions of the activins and BMPs during testicular development and spermatogenesis, then it would appear that this role can be played by the circulating form of follistatin, namely follistatin 315 .

Clearly, for the grafted testes to grow 50-100-fold in volume, the blood vessels of the host RAG mice have invaded the testis and provided the necessary blood supply. These vessels are able to deliver circulating follistatin to the inter-tubular areas and, since the vascular endothelium can synthesize follistatin, this tissue could act as a local source of both forms of follistatin (Michel et al. 1996). However, as the seminiferous tubule is an avascular compartment, the follistatin can only be made available to the spermatogonia and Sertoli cells, both of which abut the basement membrane of the seminiferous tubule. Any requirement by the more luminally placed germ cells for follistatin can only be provided by transport by the Sertoli cells due to the presence of the inter-Sertoli cell tight junctions that comprise the basis of the blood-testis barrier. Gonocytes, spermatogonia and Sertoli cells, which have been shown to require follistatin to modulate the actions of activin $\mathrm{A}$ during testicular development, can access follistatin from the host vasculature. If follistatin plays a crucial role in the physiology of primary spermatocytes and spermatids, cells in which it has been localised (Meinhardt et al. 1998), then, in the follistatin null testis, this must be provided by transport through the Sertoli cell.

This study also demonstrates the feasibility of using the external ear as a site for successfully transplanting the testis in mice. While this technique has been successfully used in the rat (Johnson et al. 1996), this study represents the first report of this technique in mice. The successful completion of spermatogenesis at this site is probably due to the lower temperature of the pinna and its rich vascular supply.

This study also demonstrates that it is feasible to successfully generate sperm from genetically modified mice that die at birth and raise the possibility that these sperm could be used to generate homozygous mice by the use of assisted reproductive techniques. Alternatively, the successful transplantation of testes to the flank 
of nude mice as demonstrated by Honaramooz et al. (2002) may provide a technically less demanding approach.

\section{Acknowledgements}

This study was supported by NHMRC Program Grant No 334011 to D M de K and J R M and in part by National Institutes of Health Grant HD32067 to M M M The authors declare that there is no conflict of interest that would prejudice the impartiality of this scientific work.

\section{References}

Buzzard JJ, Farnworth PG, de Kretser DM, O'Connor AE, Wreford NG \& Morrison J 2003 Proliferative phase Sertoli cells display a developmentally regulated response to activin in vitro. Endocrinology 144 474-483.

Esch FS, Shimasaki S, Mercado M, Cooksey K, Ling N, Ying S, Ueno N \& Guillemin R 1987 Structural characterization of follistatin: a novel follicle-stimulating hormone release-inhibiting polypeptide from the gonad. Molecular Endocrinology 1 849-855.

Glister C, Kemp CF \& Knight PG 2004 Bone morphogenetic protein (BMP) ligands and receptors in bovine ovarian follicle cells: actions of BMP-4,-6 and -7 on granulosa cells and differential modulation of Smad-1 phosphorylation by follistatin. Reproduction 127 239-245.

Guo Q, Kumar TR, Woodruff T, Hadsell LA, DeMayo FJ \& Matzuk MM 1998 Overexpression of mouse follistatin causes reproductive defects in transgenic mice. Molecular Endocrinology 12 96-106.

Hakovirta H, Kaipia A, Soder O \& Parvinen M 1993 Effects of activin-A, inhibin-A, and transforming growth factor-beta 1 on stage-specific deoxyribonucleic acid synthesis during rat seminiferous epithelial cycle. Endocrinology 133 1664-1668.

Honaramooz A, Snedaker A, Boiani M, Scholer H, Dobrinski I \& Schlatt S 2002 Sperm from neonatal mammalian testes grafted in mice. Nature 418 778-781.

lemura S, Yamamoto TS, Takagi C, Uchiyama H, Natsume T, Shimasaki S, Sugino H \& Ueno N 1998 Direct binding of follistatin to a complex of bone-morphogenetic protein and its receptor inhibits ventral and epidermal cell fates in early Xenopus embryo. PNAS 95 9337-9342.

Johnson L, Suggs LC, Norton YM \& Zeh WC 1996 Effect of developmental age or time after transplantation on Sertoli cell number and testicular size in inbred Fischer rats. Biology of Reproduction 54 948-959.

Lawson KA, Dunn NR, Roelen BA, Zeinstra LM, Davis AM, Wright CV, Korving JP \& Hogan BL 1999 Bmp4 is required for the generation of primordial germ cells in the mouse embryo. Genes and Development 13 424-436.

Ling N, Ying SY, Ueno N, Shimasaki S, Esch F, Hotta M \& Guillemin R 1986 Pituitary FSH is released by a heterodimer of the beta-subunits from the two forms of inhibin. Nature 321 779-782.

Mather JP, Attie KM, Woodruff TK, Rice GC \& Phillips DM 1990 Activin stimulates spermatogonial proliferation in germ-Sertoli cell cocultures from immature rat testis. Endocrinology 127 3206-3214.

Mather JP, Roberts PE \& Krummen LA 1993 Follistatin modulates activin activity in a cell- and tissue-specific manner. Endocrinology 132 2732-2734.
Matzuk MM, Lu N, Vogel H, Sellheyer K, Roop DR \& Bradley A 1995 Multiple defects and perinatal death in mice deficient in follistatin. Nature 374 360-363.

Meehan T, Schlatt S, O'Bryan MK, de Kretser DM \& Loveland KL 2000 Regulation of germ cell and Sertoli cell development by activin, follistatin and FSH. Developmental Biology 220 225-237.

Meinhardt A, O'Bryan MK, McFarlane JR, Loveland KL, Mallidis C, Foulds LM, Phillips DJ \& de Kretser DM 1998 Localization of follistatin in the rat testis. Journal of Reproduction and Fertility 112 233-241.

Michel U, Schneider O, Kirchof C, Meisel S, Smirnov A, Wiltfang J \& Rieckmann P 1996 Production of follistatin in porcine endothelial cells: differential regulation by bacterial compounds and the synthetic glucocorticoid RU 28362. Endocrinology 137 4925-4934.

Nakamura T, Takio K, Eto Y, Shibai H, Titani K \& Sugino H 1990 Activin-binding protein from rat ovary is follistatin. Science $\mathbf{2 4 7}$ 836-838.

Robertson DM, Foulds LM, Leversha L, Morgan FJ, Hearn MT, Burger HG, Wettenhall REH \& de Kretser DM 1985 Isolation of inhibin from bovine follicular fluid. Biochemical and Biophysical Research Communications 126 220-226.

Robertson DM, Klein R, de Vos FL, McLachlan RI, Wettenhall RE, Hearn MTW, Burger HG \& de Kretser DM 1987 The isolation of polypeptides with FSH suppressing activity from bovine follicular fluid which are structurally different to inhibin. Biochemical and Biophysical Research Communications 149 744-749.

Tanimoto Y, Tanimoto K, Sugiyama F, Horiguchi H, Murakami K, Yagami K \& Fukamizu A 1999 Male sterility in transgenic mice expressing activin betaA subunit gene in testis. Biochemical and Biophysical Research Communications 259 699-705.

Ueno N, Ling N, Ying SY, Esch F, Shimasaki S \& Guillemin R 1987 Isolation and partial characterization of follistatin: a single-chain Mr 35000 monomeric protein that inhibits the release of folliclestimulating hormone. PNAS 84 8282-8286.

Vale W, Rivier J, Vaughan J, McClintock R, Corrigan A, Woo W, Karr D \& Spiers D 1986 Purification and characterization of an FSH releasing protein from porcine ovarian follicular fluid. Nature 321 776-779.

van Dissel-Emiliani FM, Grootenhuis AJ, de Jong FH \& de Rooij DG 1989 Inhibin reduces spermatogonial numbers in testes of adult mice and Chinese hamsters. Endocrinology 125 1899-1903.

Ying Y, Liu XM, Marble A, Lawson KA \& Zhao GQ 2000 Requirement of Bmp8b for the generation of primordial germ cells in the mouse. Molecular Endocrinology 14 1053-1063.

Zhao GQ, Deng K, Labosky PA, Liaw L \& Hogan BL 1996 The gene encoding bone morphogenetic protein $8 \mathrm{~B}$ is required for the initiation and maintenance of spermatogenesis in the mouse. Genes and Development 10 1657-1669.

Zhao GQ, Liaw L \& Hogan BL 1998 Bone morphogenetic protein 8A plays a role in the maintenance of spermatogenesis and the integrity of the epididymis. Development 125 1103-1112.

Received 8 March 2006

First decision 21 April 2006

Revised manuscript received 26 June 2006

Accepted 10 July 2006 